\title{
Draft genome sequence of the coccolithovirus EhV-84
}

\author{
Jozef I. Nissimov ${ }^{1}$, Charlotte A. Worthy ${ }^{1,2}$, Paul Rooks ${ }^{1}$, Johnathan A. Napier ${ }^{2}$, Susan A. \\ Kimmance ${ }^{1}$, Matthew R Henn ${ }^{3}$, Hiroyuki Ogata ${ }^{4}$, Michael J. Allen ${ }^{1 *}$ \\ ${ }^{1}$ Plymouth Marine Laboratory, Prospect Place, The Hoe, Plymouth, PL1 3DH, UK \\ ${ }^{2}$ Department of Biological Chemistry, Rothamsted Research, Harpenden, Herts AL5 \\ 2JQ \\ ${ }^{3}$ The Broad Institute of MIT and Harvard, Cambridge, Massachusetts, United States \\ of America \\ ${ }^{4}$ Structural and Genomic Information Laboratory, CNRS-UPR2589, Mediterranean Institute \\ of Microbiology (IFR-88), Aix-Marseille University, 163 avenue de Luminy Case 934, FR- \\ 13288 Marseille, France
}

*Corresponding author: Michael J. Allen (mija@pml.ac.uk)

Keywords: coccolithovirus, marine, phycodnavirus, algae, virus

The Coccolithoviridae is a recently discovered group of viruses that infect the marine coccolithophorid Emiliania huxleyi. Emiliania huxleyi virus 84 (EhV-84) has a $160-180 \mathrm{~nm}$ diameter icosahedral structure and a genome of approximately $400 \mathrm{kbp}$. Here we describe the structural and genomic features of this virus, together with a near complete draft genome sequence $(\sim 99 \%)$ and its annotation. This is the fourth genome sequence of a member of the coccolithovirus family.

\section{Introduction}

Coccolithoviruses infect the cosmopolitan marine microalgae, Emiliania huxleyi [1]. These algae are capable of forming vast blooms which can be seen from space and can cover up to $100,000 \mathrm{~km}^{2}$ occurring in the top 50-100 m of the water column, with a cellular density of more than a million cells per liter of seawater [2]. E. huxleyi has become a species crucial to the study of global biogeochemical cycling [3-5]. The elegant calcium carbonate scales (known as coccoliths) which it produces intracellularly and the scale of its blooms have made E. huxleyi an essential model organism for marine primary productivity and global carbon cycling [6]. Coccolithoviruses have been shown to be a major cause of coccolithophore bloom termination and their pivotal role in global biogeochemical cycling has gained increasing attention. Coccolithovirus abundances typically reach $10^{7}$ per ml in natural seawater under bloom conditions and $10^{8}-10^{9}$ per $\mathrm{ml}$ under laboratory culture. The model coccolithovirus strain EhV-86 (AJ890364), and two other similar but genetically distinct strains, EhV-84 and EhV-88 were isolated in 1999 from a coccolithophore bloom in the English Channel. EhV-86 was sequenced in its entirety in
2005 to reveal a genome of 407,339 bp. Two further strains, EhV-163 and EhV-99B1 were isolated in 2000 and 1999 respectively from a Norwegian fjord and have had their partial genomes also sequenced $[7,8]$. All coccolithoviruses known to date have been isolated from the English Channel and a Norwegian fjord. Here we present a summary classification and a set of features for coccolithovirus strain EhV-84, the second English Channel coccolithovirus sequenced, together with the description of the sequencing and annotation of its genome.

\section{Classification and features}

All coccolithoviruses to date have been isolated from E. huxleyi algal blooms in temperate and sub temperate oceanic waters. Maximum likelihood phylogenetic analysis of available DNA polymerase gene sequences (DNA pol), one of the viral kingdom's phylogenetic markers (equivalent to $16 \mathrm{~S}$ rDNA sequences in bacteria) indicates that the closest related viral strain to EhV-84 is EhV-86 and EhV-88 (Figure 1). Both of these strains were isolated from the English Channel in the same year 
as EhV-84 [13]. The English Channel EhVs that were isolated in 1999 (EhV-84, EhV-86 and EhV88) are more similar to other strains from the English Channel such as EhV-201, EhV-203, EhV207 and EhV-208 isolated two years later in 2001, than strains such as EhV-163 and EhV-99B1 that are from a different geographical location; i.e. a Norwegian fjord. Interestingly EhV-202 seems to be the most different of all strains sequenced to date and this is also evident from full genome sequencing (data not published). Other algal viruses such as Paramecium bursaria Chlorella virus
(PBCV-1), Micromonas pusilla virus SP1 (MpVSP1), Chrysochromulina brevifilum virus PW1 (CbV-PW1), Ectocarpus siliculosus virus 1 (EsV-1), Heterosigma akashiwo virus 01 (HaV-01) are included here as an additional reference and they cluster outside the EhVs genus. The EhV-84 virion structure has icosahedral morphology, a diameter of $160-180 \mathrm{~nm}$ (Figure 2), and is similar to other coccolithoviruses (and phycodnaviruses in general) [14]. Isolation and general phylogenetic characteristics are outlined in Table 1.

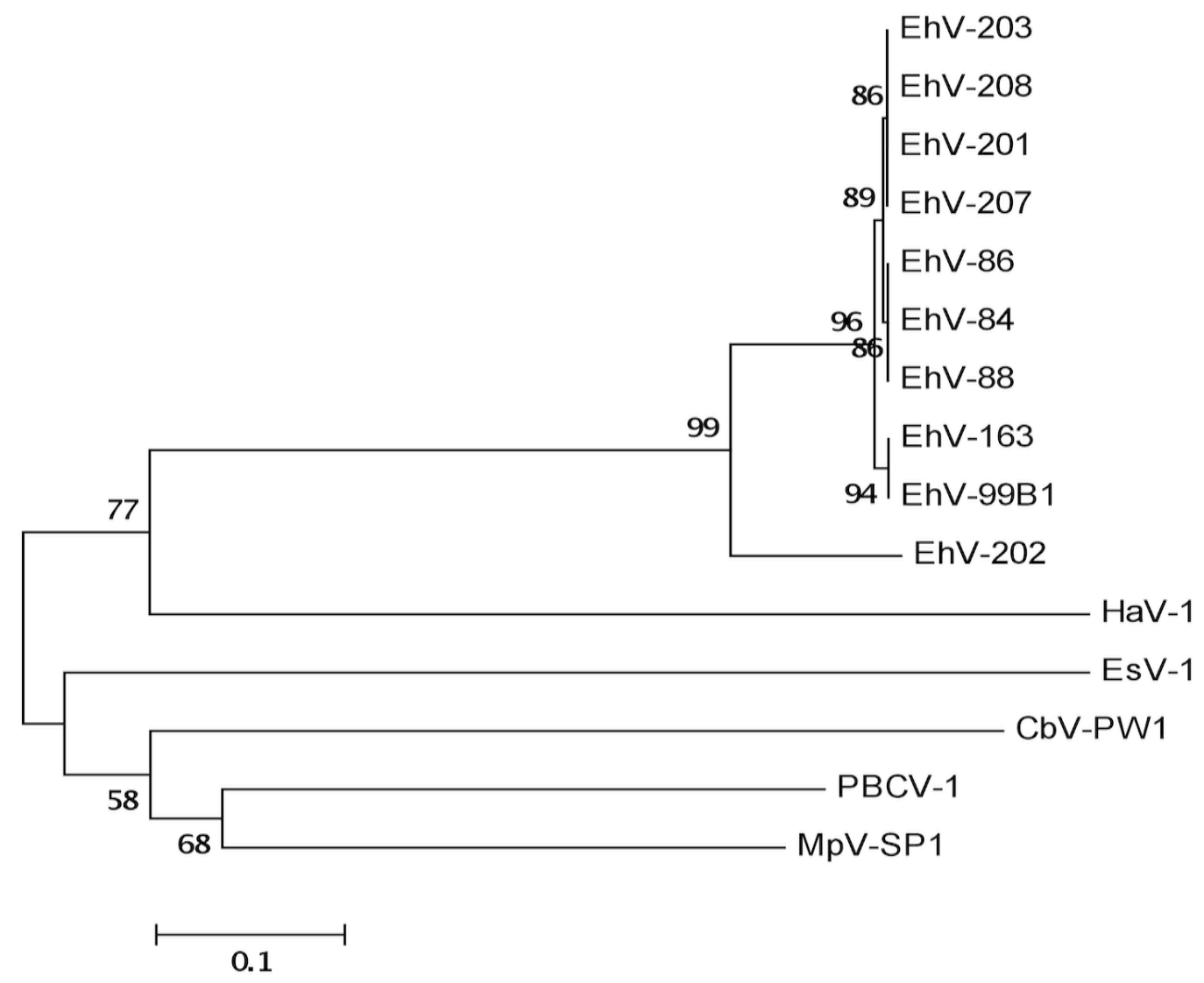

Figure 1. Multiple Sequence Alignment of the DNA pol (DNA polymerase) gene of ten coccolithoviruses (EhVs) and five other algal viruses. The evolutionary history was inferred using the Neighbor-Joining method [9]. The bootstrap consensus tree inferred from 1000 replicates is taken to represent the evolutionary history of the taxa analyzed [10]. The percentage of replicate trees in which the associated taxa clustered together in the bootstrap test (1000 replicates) are shown next to the branches when greater than 50\% [10]. The evolutionary distances were computed using the Maximum Composite Likelihood method [11] and are in the units of the number of base substitutions per site. All positions containing gaps and missing data were eliminated from the dataset (Complete deletion option). Phylogenetic analyses were conducted in MEGA4 [12]. 
Table 1. Classification and general features of Emiliania huxleyi virus 84 according to the MIGS recommendations [15].

\begin{tabular}{llll}
\hline MIGS ID & Property & Term & Evidence code \\
\hline & & Domain: Viruses, dsDNA viruses, no RNA stage & TAS [16] \\
& Current classification & Class: NCLDNA (Nucleo-Cytoplasmic Large DNA) & TAS [16] \\
& & Genus: Coccolithovirus & TAS [16] \\
& \multirow{2}{*}{ Virion shape } & Species: Emiliania huxleyi virus 84 & TAS [16] \\
MIGS-6 & Habitat & Icosahedral & TAS [16] \\
MIGS-15 & Biotic relationship & Obligate intracellular parasite of Emiliania huxleyi & TAS [16] \\
MIGS-14 & Pathogenicity & Lytic virus of Emiliania huxleyi & TDA [16] \\
MIGS-4 & Geographic location & English Channel, UK & TAS [16] \\
MIGS-5 & Sample collection time & July 26, 1999 & TAS [16] \\
MIGS-4.1 & Latitude & $50.15 \mathrm{~N}$ & TAS [16] \\
MIGS-4.2 & Longitude & $4.13 \mathrm{E}$ & TAS [16] \\
MIGS-4.3 & Depth & $15 \mathrm{~m}$ & TAS [16] \\
\hline
\end{tabular}

Evidence codes - IDA: Inferred from Direct Assay; TAS: Traceable Author Statement (i.e., a direct report exists in the literature); NAS: Non-traceable Author Statement (i.e., not directly observed for the living, isolated sample, but based on a generally accepted property for the species, or anecdotal evidence). These evidence codes are from the Gene Ontology project [17].

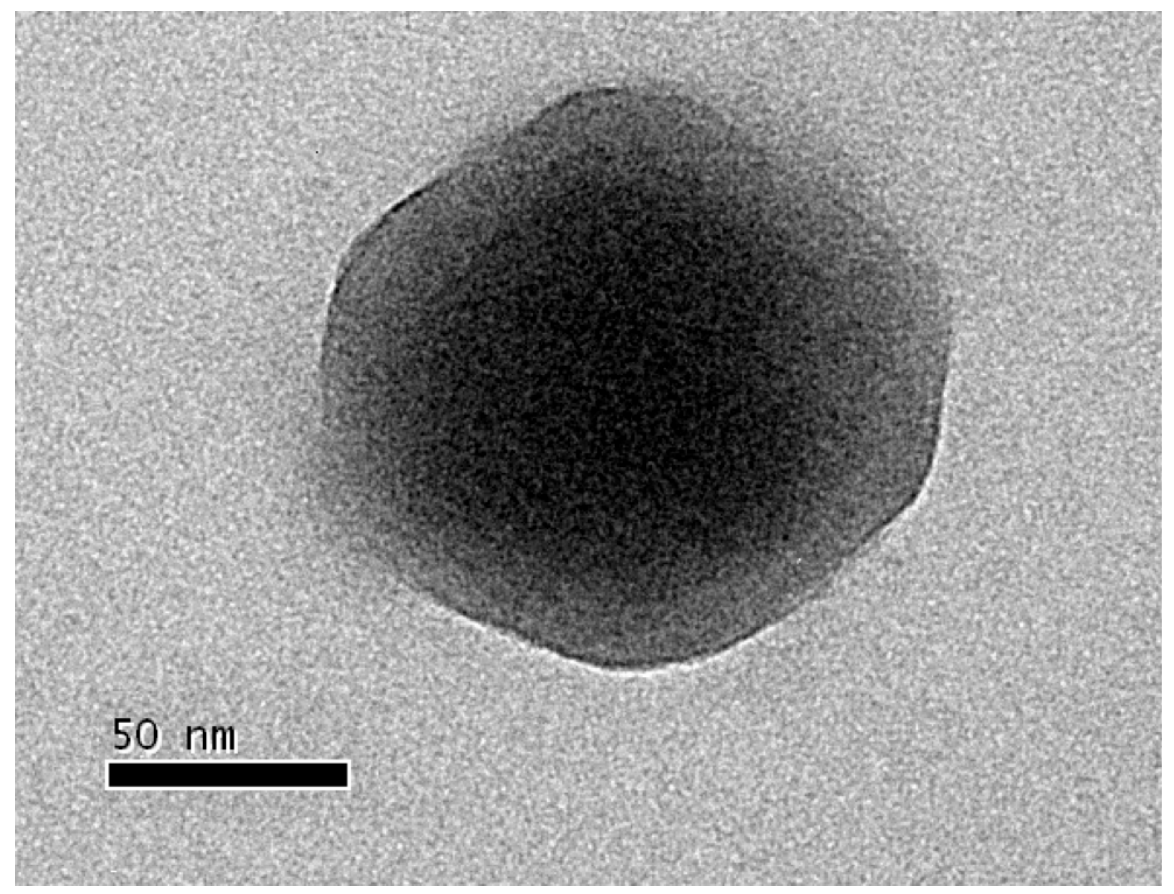

Figure 2. Transmission electron micrograph of an EhV-84 virion. 


\section{Genome sequencing and annotation Genome project history}

The Marine Microbiology Initiative (MMI) of the Gordon \& Betty Moore Foundation aims to generate new knowledge about the composition, function, and ecological role of the microbial communities that serve as the basis of the food webs of the oceans and that facilitate the flow of nitrogen, carbon, and energy in the ocean. In an effort to understand the ecology and evolution of marine phage and viruses and to explore the diversity and ecological roles of entire phage/viral communities through metagenomics, the Broad Institute collaborated with MMI and researchers whose sequencing nominations were chosen by the Marine Phage, Virus, and Virome Selection Committee to generate genomic sequence and annotation of ecologically important phage. EhV-84 was nominated for sequencing on the basis of its global importance in the demise of E. huxleyi blooms [13], the horizontal gene transfer events observed in other coccolithovirus genomes [18], the metabolic potential displayed by its large genome size and its possible manipulation of signaling pathways such as programmed cell death in its host organism $[8,19]$.

The genome project is deposited in the The Integrated Microbial Genomes (IMG) system and the complete genome sequence and annotation are available in GenBank (JF974290). Genome sequencing, finishing and annotation were performed by the Broad Institute. A summary of the project information is shown in Table 2.

Table 2. Genome sequencing project information

\begin{tabular}{lll}
\hline MIGS ID & Property & Term \\
\hline MIGS-31 & Finishing quality & Finished (>99\%) \\
& Number of contigs & 9 \\
& Average contig size & 43,980 \\
& Largest contig size & 97,445 \\
& Assembly size (using large contigs) & 395,820 \\
& Assembly coverage ("peak Depth") & 36.16 \\
& Total number of reads used & 28,526 \\
MIGS-29 & Sequencing platforms & 454 \\
MIGS-30 & Assemblers & Newbler Version 2.3 PostRelease-11.19.2009 \\
MIGS-32 & Gene calling method & Broad Institute Automated Phage Annotation Protocol [20] \\
& GenBank ID & N/A \\
& GOLD ID & Gordon \& Betty Moore Foundation's Marine Microbiology \\
& Project relevance & Initiative. Emiliania huxleyi virus 84- G3248. \\
\hline
\end{tabular}

\section{Growth conditions and DNA isolation}

Emiliania huxleyi strain CCMP 2090 was grown in 1 liter cultures (f/2 nutrient media) in the laboratory under a light/dark cycle of $16 / 8$ respectively, at a temperature of $16^{\circ} \mathrm{C}$. Once the cultures were at mid exponential growth (i.e. $4 \times 10^{6} \mathrm{ml}^{-1}$ ), they were infected with an EhV-84 lysate at an MOI ratio of 1:1. Infection, host death and viral production were confirmed by flow cytometry. Fresh virus lysate was filtered through a $0.2 \mu \mathrm{m}$ pore 47 $\mathrm{mm}$ diameter Durapore filter (Millipore). Viruses were concentrated by PEG precipitation, subjected to a $\mathrm{CsCl}$ gradient and the DNA extracted $[8,21]$.

\section{Genome sequencing and assembly}

The genome of strain EhV-84 was sequenced using the 454 FLX pyrosequencing platform (Roche/454, Branford, CT, USA). Library construction, and sequencing were performed as previously described [20]. General protocols for library construction can be found at [22]. De novo genome assembly of resulting reads was performed using the Newbler v2.3 assembly software package as previously described [20]. Assembly metrics are as described in Table 3. 
Table 3. De novo assembly metrics for EhV-84

\begin{tabular}{cccccc}
$\begin{array}{c}\text { No. of Reads } \\
\text { Assembled }\end{array}$ & No. of Contigs & $\begin{array}{c}\text { Largest Contig } \\
(\mathbf{b p})\end{array}$ & $\begin{array}{c}\text { Total Contig } \\
\text { Length (bp)* }\end{array}$ & $\begin{array}{c}\text { Average } \\
\text { Contig } \\
\text { Sequence } \\
\text { Coverage }\end{array}$ & $\begin{array}{c}\text { Percent of } \\
\text { Bases Q40 }\end{array}$ \\
\hline 28,526 & 9 & 97,445 & 395,820 & $36.9 \pm 3.6$ & 94.9 \\
\hline
\end{tabular}

*Total contig length does not include bp for gaps of unknown size

\section{Genome annotation}

Genes were identified using the Broad Institute Automated Phage Annotation Protocol as previously described [20]. In short, evidence based and $a b$ initio gene prediction algorithms where used to identify putative genes followed by construction of a consensus gene model using a rulesbased evidence approach. Gene models where manually checked for errors such as in-frame stops, very short proteins, splits, and merges. Additional gene prediction analysis and functional annotation was performed within the Integrated Microbial Genomes - Expert Review platform [23].

\section{Genome properties}

General features of the EhV-84 genome sequence (Table 4) include a nucleotide composition of $40.17 \% \mathrm{G}+\mathrm{C}$ (Figure 3), a total of 482 predicted protein coding genes and four tRNA genes (encoding amino acids Arg, Asn, Gln and Ile). Of the 482 CDSs, 85 (17.49\%) have been annotated with functional product predictions (Table 4) and the genes have been categorized into COGs functional groups (Table 5).

\section{Insights from the genome sequence Comparative genomics}

EhV-84 is now the fourth coccolithovirus strain to have its genome determined. EhV-84 displays a near identical $\mathrm{G}+\mathrm{C}$ content to $\mathrm{EhV}-86$; i.e. $40.17 \%$ and $40.18 \%$ respectively. EhV-84 is predicted to encode 482 coding sequences (including 18 pseudogenes) and four tRNA genes (Arg, Asn, Gln and Ile), whereas EhV-86 has 472 CDSs and five tRNAs (Arg, Asn, Gln, Ile and Leu). Two of the EhV-84 tRNAs are identical in length and sequence to tRNAs in EhV-86 (Gln, 72 bases; Asn, 74 bases), one is $98 \%$ similar (Arg, 72 bases in EhV-84; 73 bases in EhV-86). However, the Ile tRNA of EhV-84 varies dramatically, containing a 26 base intron insertion (99 bases in EhV-84; 73 bases in EhV86). EhV-86 has an extra Leu (103 bases) that is absent from the genome of $\mathrm{EhV}-84$.

Table 4. Genome statistics of EhV-84

\begin{tabular}{lrr}
\hline Attribute & Value & \% of total $^{\mathbf{a}}$ \\
\hline Size (bp) & 396,620 & $100.00 \%$ \\
G+C content (bp) & 158,983 & $40.17 \%$ \\
Coding region (bp) & 334,463 & $84.33 \%$ \\
Total genes $^{\mathrm{b}}$ & 486 & $100.00 \%$ \\
RNA genes & 4 & $0.82 \%$ \\
Protein-coding genes & 482 & $99.18 \%$ \\
Protein coding genes with function prediction & 85 & $17.49 \%$ \\
Genes in paralog clusters & 15 & $3.09 \%$ \\
Genes with signal peptides & 142 & $29.22 \%$ \\
\hline
\end{tabular}

aThe total is based on either the size of the genome in base pairs or the total number of protein coding genes in the annotated genome, where applicable.

bincludes 18 pseudogenes. 


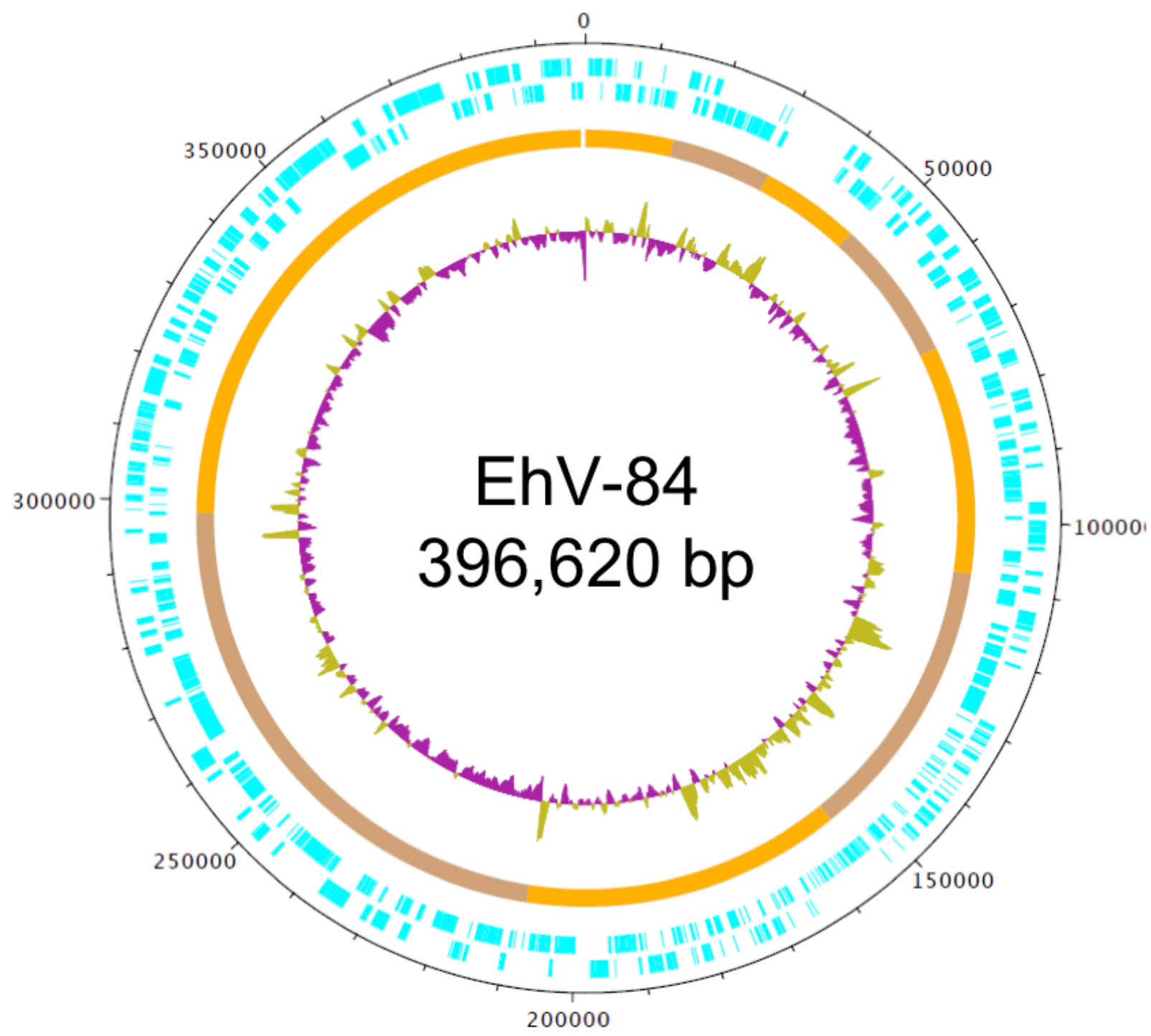

Figure 3. Graphical circular map of the 396,620 bp EhV-84 genome. The outside scale is numbered clockwise in bp. Circles 1 and 2 (from outside in) denotes CDSs (forward and reverse strands, respectively). Circle 3 represents the nine contigs of the genome that were used to construct the draft genome using the EhV-86 genome as the reference, and circle 4 is the $\mathrm{G}+\mathrm{C}$ content.

There are 224 CDSs in EhV-84 which share 100\% sequence identity (TBLASTN) with homologues in EhV-86. A further 198 CDSs have non-identical homologues in EhV-86, with similarities greater than $10 \%$ (settings in IMG/ER: TBLASTN, Max e-value $1 \mathrm{e}-5$, min. percent identity 10 , algorithm by present/absent homologs, min. taxon percent with homologs 100, min. taxon percent without homologs 100). Of the CDSs shared between EhV-84 and EhV-86, 69 have an assigned function in EhV-86 that also corresponds to sequences in the Conserved Domain Database (Table 6). More than half $(38 / 69)$ are identical in both strains. In addition, there are a further 60 annotated CDSs in EhV-84 which have no homologues in EhV-86, two of which have homologues in EhV-99B1 (ENVG00303 and ENVG00419, encoding a hypothetical protein and zinc finger protein, respectively). Three of the unique EhV-84 CDSs show similarity to sequences in the Conserved Domain Dataset [23]. ENVG00283 contains a transposase DNA-binding domain and is $1,953 \mathrm{bp}$ long. This domain is commonly found at the C-terminus of a large number of transposase proteins. ENVG00294 contains a DNA polymerase III gamma and tau subunit domain and is 1,551 bp long and ENVG00066 contains a methyltransferase type FkbM family domain and is 908 bp long. 
Table 5. Number of genes associated with COG functional categories.

\begin{tabular}{cccl}
\hline Code & value & \%age & Description \\
\hline G & 1 & 1.41 & Carbohydrate transport and metabolism \\
D & 3 & 4.23 & Cell cycle control, cell division, chromosome partitioning \\
M & 2 & 2.82 & Cell wall/membrane/envelope biogenesis \\
H & 2 & 2.82 & Coenzyme transport and metabolism \\
S & 6 & 8.45 & Function unknown \\
R & 7 & 9.86 & General function prediction only \\
P & 1 & 1.41 & Inorganic ion transport and metabolism \\
U & 2 & 2.82 & Intracellular trafficking, secretion, and vesicular transport \\
I & 5 & 7.04 & Lipid transport and metabolism \\
F & 6 & 8.45 & Nucleotide transport and metabolism \\
O & 8 & 11.27 & Posttranslational modification, prot. turnover, chaperones \\
L & 11 & 15.49 & Replication, recombination and repair \\
A & 4 & 5.63 & RNA processing and modification \\
T & 1 & 1.41 & Signal transduction mechanisms \\
K & 12 & 16.90 & Transcription \\
\hline
\end{tabular}

\section{Sphingolipid biosynthesis}

EhV-84 shares the same sphingolipid LCB biosynthetic machinery as EhV-86 (all predicted components share $100 \%$ sequence identity, see Table 6). Interestingly, like EhV-86, EhV-84 also lacks a critical sphingolipid LCB biosynthetic activity, 3ketosphinganine reductase [19]. There is now increasing evidence to suggest that these viral sphingolipid genes encode proteins that act in conjunction with the algal host sphingolipid biosynthetic genes to generate bioactive lipid(s). Indeed, ehv050 has been shown to encode a functional serine myristoyl transferase, and its expression has been observed under both laboratory and natural environmental conditions [24-26]. The perfect conservation of these genes suggests both a strong selection pressure and/or a relatively recent shared history between these EhV-84 and EhV-86 genes. The presence of the sphingolipid pathway on coccolithovirus genomes emphasizes the important co-evolutionary dynamics that occur within natural oceanic communities: the genes are examples of horizontal gene transfer events between the viruses and their host.

\section{Phylogeny: DNA pol and MCP}

Two genes, encoding DNA polymerase (DNA pol) and the capsid protein (MCP) have been extensively used as marker genes for different $\mathrm{EhV}$ strains within the phycodnavirus family and for the study of coccolithovirus diversity $[24,27,28]$. In EhV-86 the MCP gene (ehv085) is 1,602 bp long and DNA pol (ehv030) is 3,039 bp long. These protein coding sequences are often viewed as the viral kingdom's equivalent to $16 \mathrm{~S}$ rDNA marker genes in bacteria, and are therefore commonly used in phylogenetic studies (Figure 1) [29]. DNA pol seems to be highly conserved in coccolithoviruses. For instance, despite their large size, ehv030 in the reference genome of EhV-86 and its homolog ENVG00144 in EhV-84 share a 100\% identity to each other at the nucleotide level. In contrast, the MCP gene of EhV-86 (ehv085) and its homolog in EhV-84 (ENVG00202) are more variable, particularly in the $5^{\prime}$ and $3^{\prime}$ regions. Associated structural differences in MCP as a consequence of this variation may form the bases of the phenotypic diversity displayed by the coccolithoviruses with regards to host range. Such structural differences may also benefit the virus in its purpose of successfully infecting and attaching to the targeted host cells. The evolutionary arms race between the host and the virus is something that the virus must take into account and adapt to; and this might explain why this gene is so variable between strains. 
These two common marker genes reveal an interesting pattern between EhV-86 and EhV-84. On the whole, the genomes are highly similar, yet subtle and some large (and potentially crucial) genetic differences do occur. The apparent difference in evolutionary divergence rates of core components such as DNA pol and MCP genes is intriguing and suggests that lateral transfer of material between different coccolithovirus genomes may be prevalent in the natural environment. The DNA pol gene may have a more recent shared evolutionary history than its MCP counterpart in the EhV-86/EhV84 system. Through the sequencing of further strains we hope to shed light on this intriguing dynamic.

Table 6. CDSs with functional predictions identified in both EhV-84 and EhV-86 genomes [1] ${ }^{\dagger}$.

\begin{tabular}{|c|c|c|}
\hline CDS & EhV-86 homologs (putative function/feature) & $\begin{array}{c}\text { Identity to EhV-86 } \\
\text { homologue }(\%)\end{array}$ \\
\hline ENVG 00127 & ehv014 Longevity-assurance (LAG1) family protein & 100 \\
\hline ENVG 00131 & ehv018 flap endonuclease- 1 & 100 \\
\hline ENVG 00133 & ehv020 putative proliferating cell nuclear antigen & 99.61 \\
\hline ENVG 00134 & ehv021 putative serine protease & 100 \\
\hline ENVG 00135 & ehv022 phosphoglycerate mutase family protein & 99.07 \\
\hline ENVG 00136 & ehv023 putative deoxycytidylate (dCMP) deaminase & 98.27 \\
\hline ENVG 00139 & ehv026 ribonucleoside-diphosphate reductase small subunit & 99.38 \\
\hline ENVG 00142 & ehv028 putative lipase & 100 \\
\hline ENVG 00144 & ehv030 putative DNA polymerase delta catalytic subunit & 100 \\
\hline ENVG $00145^{1}$ & ehv031 putative sterol desaturase & 100 \\
\hline ENVG 00149 & ehv035 putative membrane protein & 100 \\
\hline ENVG 00156 & ehv041 putative endonuclease & 58.33 \\
\hline ENVG $00165^{1}$ & ehv050 serine myristoyl transferase & 100 \\
\hline ENVG 00176 & ehv060 putative lectin protein & 100 \\
\hline ENVG $00177^{2}$ & ehv061 putative fatty acid desaturase & 100 \\
\hline ENVG 00178 & ehv062 putative membrane protein & 100 \\
\hline ENVG 00180 & ehv064 DNA-dependent RNA polymerase II largest subunit & 100 \\
\hline ENVG 00181 & ehv064 DNA-dependent RNA polymerase II largest subunit beta & 100 \\
\hline ENVG $00194^{1}$ & ehv077 putative transmembrane fatty acid elongation protein & 100 \\
\hline ENVG $00196^{1}$ & ehv079 putative lipid phosphate phosphatase & 100 \\
\hline ENVG 00202 & ehv085 major capsid protein & 99.81 \\
\hline ENVG 00205 & ehv088 putative membrane protein & 99.02 \\
\hline ENVG 00382 & ehv101 putative hydrolase & 100 \\
\hline ENVG 00380 & ehv103 putative vesicle-associated membrane protein & 100 \\
\hline ENVG 00379 & ehv104 putative DNA helicase & 99.81 \\
\hline ENVG 00378 & ehv105 transcription factor S-II (TFIIS) family protein & 100 \\
\hline ENVG 00375 & ehv108 putative DNA-directed RNA polymerase subunit & 100 \\
\hline ENVG 00374 & ehv109 OTU-like cysteine protease & 100 \\
\hline ENVG 00373 & ehv110 putative RING finger protein & 100 \\
\hline ENVG 00370 & ehv113 bifunctional dihydrofolate reductase-thymidylate synthase & 99.79 \\
\hline ENVG 00367 & ehv116 putative membrane protein & 100 \\
\hline ENVG 00366 & ehv117 putative phosphate permease/ sodium-phosphate symporter & 100 \\
\hline ENVG 00356 & ehv128 ERV1/ALR family protein & 98.22 \\
\hline ENVG 00353 & ehv131 putative membrane protein & 95.08 \\
\hline ENVG 00351 & ehv133 putative ATP-dependent protease proteolytic subunit & 97.90 \\
\hline
\end{tabular}


Table 6 (cont.) CDSs with functional predictions identified in both EhV-84 and EhV-86 genomes [1] $]^{+}$.

\begin{tabular}{|c|c|c|}
\hline CDS & EhV-86 homologs (putative function/feature) & $\begin{array}{c}\text { Identity to EhV-86 } \\
\text { homologue }(\%)\end{array}$ \\
\hline ENVG 00348 & ehv136 putative nucleic acid-binding protein & 98.58 \\
\hline ENVG 00293 & ehv137 putative membrane protein & 24.90 \\
\hline ENVG 00429 & ehv151 putative serine protease & 96.94 \\
\hline ENVG 00399 & ehv166 putative RING finger protein & 97.93 \\
\hline ENVG 00400 & ehv167 putative DNA-directed RNA polymerase subunit & 100 \\
\hline ENVG 00413 & ehv179 Major Facilitator Superfamily protein/transporter & 99.63 \\
\hline ENVG 00423 & ehv187 putative membrane protein & 72.00 \\
\hline ENVG 00445 & ehv192 putative membrane protein & 94.06 \\
\hline ENVG 00478 & ehv207 putative membrane protein & 100 \\
\hline ENVG 00287 & ehv230 putative endonuclease $\mathrm{V}$ & 99.22 \\
\hline ENVG 00307 & ehv246 putative lectin protein & 96.46 \\
\hline ENVG 00232 & ehv315 putative membrane protein & 100 \\
\hline ENVG 00264 & ehv349 putative protease & 100 \\
\hline ENVG 00273 & ehv358 putative thioredoxin & 98.73 \\
\hline ENVG 00276 & ehv361 putative serine protease & 97.14 \\
\hline ENVG 00278 & ehv363 putative esterase & 97.72 \\
\hline ENVG 00002 & ehv364 putative membrane protein & 100 \\
\hline ENVG 00295 & ehv364 putative membrane protein & 34.55 \\
\hline ENVG 00035 & ehv397 putative deoxyuridine 5'-triphosphate nucleotidohydrolase & 100 \\
\hline ENVG 00037 & ehv399 putative DNA-directed RNA polymerase subunit & 100 \\
\hline ENVG 00039 & ehv401 putative ribonuclease $\mathrm{HII}$ & 99.52 \\
\hline ENVG $00054^{2}$ & ehv415 putative delta 9 acyl- lipid fatty acid desaturase & 100 \\
\hline ENVG 00055 & ehv416 putative membrane protein & 100 \\
\hline ENVG 00070 & ehv428 putative ribonucleoside-diphosphate reductase protein & 98.79 \\
\hline ENVG 00074 & ehv431 putative thymidylate kinase & 99.69 \\
\hline ENVG 00077 & ehv434 putative DNA-directed RNA polymerase II subunit B & 99.74 \\
\hline ENVG 00083 & ehv440 putative proliferating cell nuclear antigen & 100 \\
\hline ENVG 00087 & ehv444 putative DNA topoisomerase & 99.64 \\
\hline ENVG 00091 & ehv447 putative serine protease & 100 \\
\hline ENVG 00095 & ehv451 putative protein kinase & 100 \\
\hline ENVG 00097 & ehv453 putative mRNA capping enzyme & 99.47 \\
\hline ENVG 00100 & ehv455 putative sialidase & 100 \\
\hline ENVG 00104 & ehv459 putative nucleic acid independent nucleoside triphosphatase & 100 \\
\hline ENVG 00111 & ehv465 putative thioredoxin protein & 100 \\
\hline
\end{tabular}

${ }^{+}$including their sequence homologs (coding sequences) in EhV-84 based on TBLASTN (translated nucleotide database)

'genes involved in sphingolipid biosynthesis

${ }^{2}$ genes encoding desaturases

\section{Conclusions}

EhV-84 is the fourth member of the coccolithovirus family to be sequenced to date. The genome reveals novel putative protein coding sequences, many of which have no current matches in the sequence databases. Many of the CDSs identified display high conservation with their counterparts in EhV-86, while a handful of highly variable CDSs suggest roles in evolutionary adaptation to their hosts and environment. Further sequencing of related strains will no doubt reveal more about the genetic and functional diversity of these cosmopolitan and environmentally important viruses. 


\section{Acknowledgments}

This research was funded in part by the Gordon and Betty Moore Foundation through a grant to the Broad Institute (MRH) and through the NERC Oceans 2025 program (MJA). Sample G3248 was sequenced, assembled and annotated at the Broad Institute. JIN is supported by a NERC studentship, CW is supported by a BBSRC Industrial CASE studentship sponsored by PML Applications. HO is supported by IGS/CNRS and ANR

\section{References}

1. Wilson WH, Schroeder DC, Allen MJ, Holden MTG, Parkhill J, Barrell BG, Churcher C, Harnlin $\mathrm{N}$, Mungall K, Norbertczak H, et al. Complete genome sequence and lytic phase transcription profile of a Coccolithovirus. Science 2005; 309:1090-1092. PubMed doi:10.1126/science.1113109

2. Coyle KO, Pinchuk Al. Climate-related differences in zooplankton density and growth on the inner shelf of the southeastern Bering Sea. Prog Oceanogr 2002; 55:177-194. doi:10.1016/S0079$\underline{6611(02) 00077-0}$

3. Brown CW, Yoder JA. Coccolithophorid Blooms in the Global Ocean. Journal of Geophysical Research-Oceans 1994; 99(C4):7467-7482. doi:10.1029/93|C02156

4. Holligan PM, Viollier M, Harbour DS, Camus P, Champagnephilippe M. Satellite and Ship Studies of Coccolithophore Production Along a Continental-Shelf Edge. Nature 1983; 304:339-342. doi:10.1038/304339a0

5. Holligan PM, Fernandez E, Aiken J, Balch WM, Boyd P, Burkill PH, Finch M, Groom SB, Malin G, Muller K, et al. A Biogeochemical Study of the Coccolithophore, Emiliania huxleyi, in the NorthAtlantic. Global Biogeochem Cycles 1993; 7:879900. doi:10.1029/93GB01731

6. Westbroek P, Brown CW, Vanbleijswijk J, Brownlee C, Brummer GJ, Conte M, Egge J, Fernandez E, Jordan R, Knappertsbusch M, et al. A Model System Approach to Biological Climate Forcing the Example of Emiliania huxleyi. Global Planet Change 1993; 8:27-46. doi:10.1016/09218181(93)90061-R

7. Schroeder DC, Oke J, Malin G, Wilson WH. Coccolithovirus (Phycodnaviridae): Characterisation of a new large dsDNA algal virus that infects Emiliania huxleyi. Arch Virol 2002; 147:1685-1698. PubMed doi:10.1007/s00705-002-0841-3

8. Allen MJ, Schroeder DC, Donkin A, Crawfurd KJ, Wilson WH. Genome comparison of two Cocco- (grant \# ANR-09-PCS-GENM-218, ANR-08-BDVA-003). We thank Konstantinos Mavromatis from JGI who assisted with information regarding the IMG/ER platform and the Broad Institute Genome Sequencing Platform, Finishing Team, and Annotation Team for their efforts to generate the genomic data. Jean Devonshire and the Centre for Bioimaging at Rothamsted provided technical support for transmission electron microscopy.

lithoviruses. Virol / 2006; 3:15. PubMed doi:10.1186/1743-422X-3-15

9. Saitou N, Nei M. The Neighbor-Joining Method a New Method for Reconstructing Phylogenetic Trees. Mol Biol Evol 1987; 4:406-425. PubMed

10. Felsenstein J. Confidence-Limits on Phylogenies an Approach Using the Bootstrap. Evolution 1985; 39:783-791. doi:10.2307/2408678

11. Tamura K, Nei M, Kumar S. Prospects for inferring very large phylogenies by using the neighborjoining method. Proc Natl Acad Sci USA 2004; 101:11030-11035. PubMed doi:10.1073/pnas.0404206101

12. Tamura K, Dudley J, Nei M, Kumar S. MEGA4: Molecular evolutionary genetics analysis (MEGA) software version 4.0. Mol Biol Evol 2007;

24:1596-1599. PubMed doi:10.1093/molbev/msm092

13. Wilson WH, Tarran GA, Schroeder D, Cox M, Oke J, Malin G. Isolation of viruses responsible for the demise of an Emiliania huxleyi bloom in the English Channel. J Mar Biol Assoc U K 2002; 82:369-377. doi:10.1017/S002531540200560X

14. Wilson WH, Van Etten JL, Allen MJ. The Phycodnaviridae: The Story of How Tiny Giants Rule the World. Lesser Known Large Dsdna Viruses 2009; 328:1-42. PubMed doi:10.1007/978-3-54068618-7_1

15. Ashburner M, Ball CA, Blake JA, Botstein D, Butler H, Cherry JM, Davis AP, Dolinski K, Dwight SS, Eppig JT, et al. Gene Ontology: tool for the unification of biology. Nat Genet 2000; 25:25-29. PubMed doi:10.1038/75556

16. Allen MJ, Martinez-Martinez J, Schroeder DC, Somerfield PJ, Wilson WH. Use of microarrays to assess viral diversity: from genotype to phenotype. Environ Microbiol 2007; 9:971-982. PubMed doi:10.1111/j.1462-2920.2006.01219.x

17. Ashburner M, Ball CA, Blake JA, Botstein D, Butler H, Cherry JM, Davis AP, Dolinski K, Dwight 
SS, Eppig JT, et al. Gene ontology: tool for the unification of biology. The Gene Ontology Consortium. Nat Genet 2000; 25:25-29. PubMed doi:10.1038/75556

18. Monier A, Pagarete A, de Vargas C, Allen MJ, Read B, Claverie JM, Ogata H. Horizontal gene transfer of an entire metabolic pathway between a eukaryotic alga and its DNA virus. Genome Res 2009; 19:1441-1449. PubMed doi:10.1101/gr.091686.109

19. Michaelson LV, Dunn TM, Napier JA. Viral transdominant manipulation of algal sphingolipids. Trends Plant Sci 2010; 15:651-655. PubMed doi:10.1016/j.tplants.2010.09.004

20. Henn MR, Sullivan MB, Stange-Thomann N, Osburne MS, Berlin AM, Kelly L, Yandava C, Kodira C, Zeng QD, Weiand M, et al. Analysis of HighThroughput Sequencing and Annotation Strategies for Phage Genomes. PLoS ONE 2010; 5:e9083. PubMed doi:10.1371/journal.pone.0009083

21. Allen MJ, Howard JA, Lilley KS, Wilson WH. Proteomic analysis of the EhV-86 virion. Proteome Sci 2008;6:11. PubMed doi:10.1186/1477-5956$\underline{6-11}$

22. The Broad Institute. Marine phage sequencing project protocols.

http://www.broadinstitute.org/annotation/viral/Ph age/Protocols.html

23. Markowitz VM, Mavromatis K, Ivanova NN, Chen IMA, Chu K, Kyrpides NC. IMG ER: a system for microbial genome annotation expert review and curation. Bioinformatics 2009; 25:2271-2278. PubMed doi:10.1093/bioinformatics/btp393
24. Pagarete A, Allen MJ, Wilson WH, Kimmance SA, de Vargas C. Host-virus shift of the sphingolipid pathway along an Emiliania huxleyi bloom: survival of the fattest. Environ Microbiol 2009; 11:2840-2848. PubMed doi:10.1111/j.14622920.2009.02006.x

25. Allen MJ, Forster T, Schroeder DC, Hall M, Roy D, Ghazal P, Wilson WH. Locus-specific gene expression pattern suggests a unique propagation strategy for a giant algal virus. J Virol 2006; 80:7699-7705. PubMed doi:10.1128/JVI.00491$\underline{06}$

26. Han G, Gable K, Yan LY, Allen MJ, Wilson WH, Moitra P, Harmon JM, Dunn TM. Expression of a novel marine viral single-chain serine palmitoyltransferase and construction of yeast and mammalian single-chain chimera. J Biol Chem 2006; 281:39935-39942. PubMed doi:10.1074/jbc.M609365200

27. Schroeder DC, Oke J, Hall M, Malin G, Wilson WH. Virus succession observed during an Emiliania huxleyi bloom. Appl Environ Microbiol 2003; 69:2484-2490. PubMed doi:10.1128/AEM.69.5.2484-2490.2003

28. Martínez JM, Schroeder DC, Larsen A, Bratbak G, Wilson WH. Molecular dynamics of Emiliania huxleyi and cooccurring viruses during two separate mesocosm studies. App/ Environ Microbiol 2007; 73:554-562. PubMed doi:10.1128/AEM.00864-06

29. Iyer LM, Balaji S, Koonin EV, Aravind L. Evolutionary genomics of nucleo-cytoplasmic large DNA viruses. Virus Res 2006; 117:156-184. PubMed doi:10.1016/j.virusres.2006.01.009 